\title{
INFLUENCE OF DIETARY ENERGY AND PROTEIN SOURCES ON DIGESTIBILITY, RUMEN PARAMETERS AND WEIGHT GAIN OF MALE GOATS
}

\section{S.A Shehata and M.A. El-Gamal}

Animal Production Dept., Faculty of Agriculture, Zagazig University, Egypt.

Nutrition and Clinical Nutrition Dept., Faculty of Veterinary Medicine, Zagazig

University, Zagazig, Egypt.

\section{ABSTRACT}

This work was carried out to study the effect of dietary energy and protein sources on digestibility, nutritive values, rumen parameters and weight gain. Twelve male goats, average body weight $20 \mathrm{~kg}$ were used in this experiment, which divided into four equal groups, fed on concentrate feed mixtures (CFM) and wheat straw ad libitum. The concentrate feed mixtures of tested rations were:

Ration $1: 70 \%$ corn $+29 \%$ cotton seed meal $+1 \%$ additives (CFM1).

Ration $2: 23 \%$ corn $+29 \%$ cotton seed $+47 \%$ SBP $+1 \%$ additives (CFM2).

Ration $3: 70 \%$ corn $+29 \%$ broken horse bean $+1 \%$ additives (CFM3).

Ration 4: $23 \%$ corn $+29 \%$ broken horse bean $+47 \%$ SBP $+1 \%$ additives (CFM4).

The CFM was offered the give goat requirements while wheat straw offered ad libitum.

The results of two energy sources showed that sugar beet pulp (SBP) has crude fiber $(C F)$, crude protein $(C P)$ and ash contents higher than corn grains content. While nitrogen free extract (NFE) and ether extract (EE) were less than corn grains. Cotton seed meal (CSM) has higher CF, EE and ash content and lower $C P$ and NFE in comparison with broken horse bean (HB).

Using of SBP instead of corn (CFM2) decreased $(P<0.05)$ the digestibility of CP, EE and NFE while the total digestible nutrients (TDN) and digestible crude protein (DCP)\% did not significantly affected. Broken horse bean $(H B)$ caused significantly $(P<0.05)$ increase in DM, OM, CF, NFE digestibility and TDN and DCP\% in comparison with (CSM). The interaction between energy and protein sources had significant $(P<0.05)$ effect on all nutrient digestibilities and nutritive values (\%). The daily body weight gain did not affect by energy sources. It was high $(P<0.05)$ for goats fed $H B$ in comparison with which fed CSM. Generally, most results indicate that the best rations were contained CFM4 followed by CFM3 followed by CFM1 then CFM2.

Results of rumen parameters showed that, the $p H$ value, ammonia nitrogen and total volatile fatty acids (TVFA's) concentrations not significantly $(P<0.05)$ affected by energy source. On the other hand, the ammonia nitrogen and TVFA's significantly $(P<0.05)$ affected by protein sources. The interaction between energy and protein sources was significant. The lowest $\mathrm{pH}$ and highest 
TVFA's were found in rumen liquor of goats fed CFM1 in comparison with fed others $(C F M)$ s. The CSM increased $(P<0.05)$ ammonia nitrogen concentration in comparison with $H B$.

Results of the study indicate that, replacing 67\% of corn of CFM1 by SBP had deleterious effect on the digestibility, nutritive values and weight gain of goat when CSM was the protein source (CFM2). On the other hand, replacing of corn by SBP with using $H B$ as protein source (CFM4) give the best results. All results indicate that $H B$ was better than CSM meal.

Key words: Dietary energy, protein sources, digestibility, rumen parameters and weight gain, male goats

\section{INTRODUCTION}

Incorporation of cheap untraditional feedstuffs such as the agro industrial by products in the animal ration may be participate in solving the problem of feed shortage in Egypt. Sugar beet pulp (SBP) is the remaining residue after sugar extraction from sugar beet tubers (Talha et al., 2002). The quantity of dried SBP in Egypt was 173326 ton, could supply 155993 ton of dry matter, 113150 ton of TDN and 6708 tons of DCP (Agriculture Economics, 2000). The SBP are fed in a significant amounts instead of corn (Graham et al., 1986; Garcia et al., 1992; ElAshry et al., 2000; Saleh et al., 2001; Talha et al.,2002 \& 2005 and Zaza, 2005). Broken horse bean (HB) is small particles of normal horse bean mixed with high amount of its hulls and used in feeding of animals.

The results of replacing corn by SBP were differed. These differences are due to substitution level; concentrate and type of energy and nitrogen (ingredients used); or synchrony of nitrogen degradation rate with carbohydrate degradation rate, percentage of concentrate in the ration, method of feeding or animal species (Casper et al., 1990; Sinclair et al., 1995 and Schmidely et al., 1999).

Therefore, this work was aimed to study the effect of replacing $67 \%$ of corn in CFM by SBP with using two sources of protein (CSM and HB) on digestibility, nutritive values, rumen parameters and weight gain of male goats.

\section{MATERIALS AND METHODS}

The experimental work on goats were carried out in Faculty of Veterinary Med. and the analysis of samples were carried out in Animal Production Dept., Faculty of Agric., Zagazig University. Factorial design (2x2) were used to study the effect of 2 energy sources (corn and SBP) and 2 protein sources (CSM and HB) on the digestibility, nutritive values, rumen parameters and weight gain of male goats (Table 1).

Twelve castrated male $20 \mathrm{~kg}$ Baladi goats were randomly assigned to four groups (3 male goats/ each group) (Table 1). Goats were fed on concentrate feed mixture (CFM) and wheat straw. Animals of $1^{\text {st }}$ group was fed on CFM consists of $70 \%$ corn $+29 \%$ cotton seed meal $+1 \%$ additives (CFM1); $2^{\text {nd }}$ group was fed on $23 \%$ 
Table (1): Formulation of concentrate feed mixtures (CFMs).

\begin{tabular}{lcccc}
\hline Items & \multicolumn{4}{c}{ Concentrate feed mixture } \\
\cline { 2 - 5 } & CFM1 & CFM2 & CFM3 & CFM4 \\
\hline Ingredient \%: & 70.0 & 23.0 & 70.0 & 23.0 \\
$\quad$ Yellow corn & 0.0 & 47.0 & 0.0 & 47.0 \\
$\quad$ Sugar beet pulp (SBP) & 29.0 & 29.0 & 0.0 & 0.0 \\
$\quad$ Cottonseed meal undecorticated & 0.0 & 0.0 & 29.0 & 29.0 \\
$\quad$ Broken horse bean & 0.70 & 0.70 & 0.70 & 0.70 \\
$\quad$ Dicalcium phosphate & $\underline{0.30}$ & $\underline{0.30}$ & $\underline{0.30}$ & $\underline{0.30}$ \\
$\quad$ Vitamin and mineral premix* & $\mathbf{1 0 0}$ & $\mathbf{1 0 0}$ & $\mathbf{1 0 0}$ & $\mathbf{1 0 0}$ \\
$\quad$ Total & & & & \\
& & & & \\
Calculated nutritive values(\%)**: & & 68.30 & 80.72 & 75.55 \\
$\quad$ TDN & 73.47 & 9.18 & 12.44 & 11.50 \\
$\quad$ DCP & 10.12 & &
\end{tabular}

*Each one kilogram of vitamins and minerals premix contains: 2000000 IU Vit. A; 150000 IU Vit. D3; 8.33 g Vit. E; 0.33 g Vit. K; 0.33 g Vit. B1; 1.0 g Vit. B2; 0.33 g Vit. B5; 1.70 g Vit. B6; 0.38 g Vit. B12; $3.33 \mathrm{~g}$ Pantothenic acid; $33 \mathrm{mg}$ Biotine; $0.83 \mathrm{~g}$ Folic acid; $200 \mathrm{~g}$ Choline chloride; $11.79 \mathrm{Zn} ; 12.50 \mathrm{~g} \mathrm{Fe} ; 0.50 \mathrm{~g} \mathrm{Cu} ; 16.6 \mathrm{Se} ; 5.0 \mathrm{~g} \mathrm{Mn}$ and $\mathrm{Mg} 66.70 \mathrm{~g}$.

**TDN and DCP\% of corn, SBP, cottonseed, bean and wheat straw were calculated 83 and 7; 72 and 5; 53 and 18; 78 and 26; 42.5 and 0.0 respectively. The above nutritive values of SBP according to (Crawshew, 1990)

corn $+47 \%$ SBP horse bean $(\mathrm{HB})+1 \%$ additives $(\mathrm{CFM} 3)$ while $4^{\text {th }}$ group fed on $23 \%$ corn $+47 \%$ SBP $+29 \% \mathrm{HB}+1 \%$ additives (CFM4). The CFM was offered the give goat requirements while wheat straw offered ad libitum.

Animals were housed individually under shaded pens and same managerial, hygienic and environmental condition. The goats fed the CFM(s) individually 2 times/ day at 8 am and $4 \mathrm{pm}$ and water was offered three times daily while wheat straw was offered ad labtium (Table 2). The CFM(s) were offered to give the theoretical requirements (maintenance, medium activity and $50 \mathrm{~g}$ weight gain / day) of goats according to (NRC, 1981).

The experiment period was 31 days ( 21 days as a preliminary period, 7 days as a collection period and 3 days for rumen parameters). Animals were weighted at first and last day of experiment. Acid insoluble ash (AIA) was used as a natural marker for nutrient digestibility determination (Van Keulen and Young, 1977). The rumen fluid samples were taken at last 3 consecutive days after 3 hours post-feeding by using rubber stomach tubes. Rumen $\mathrm{pH}$ was immediately measured using $\mathrm{pH}$ meter. The rumen liquor were filtered through two layers of surgical gauze. Ammonia-N was determined by Con-Way method (1962). Total VFA's was determined by steam distillation method as described by Warner (1964).

Proximate analysis of ingredients, CFM(s) and rations (Table 3) and feces were determined according to A.O.A.C. (1990). The results were statistically analyzed by the ANOVA as described by Snedecor and Cochran (1982), as $2 \times 2$ factorial treatment arrangement. Means were tested for differences using Duncan,s multiple range test (Duncan, 1955). 


\section{RESULTS AND DISCUSSION}

\section{Effect of energy \& protein sources and their interaction:}

\section{1- Chemical composition of $C F M(s)$ and experimental rations:}

Results presented in Table (2) showed that SBP has higher CF, CP and ash contents than corn grains. Nitrogen free extract (NFE) and EE of corn grains were higher than SBP. These results agreed with those reported by Eweedah et al. (1999) and El-Ashry et al. (2000). Cotton seed meal (CSM) had higher content of $\mathrm{CF}$, EE and ash but its CP and NFE was low comparing with broken horse bean (HB). Replacing high amount of corn $(67 \%)$ by SBP increased the CP, CF and ash in CFM2 and CFM4 but the EE and NFE content decreased. Using of HB increased the organic matter (OM), CP and NFE in CFM3 and CFM4 but the CF, $\mathrm{EE}$ and ash content decreased (Table 2) in comparison with CFM1 and CFM2 (contained CSM).

\section{2- Feed intake of goats:}

The quantity of CFM (s) which offered to goats (Table 3) was calculated according to their nutritive values (Table 1) to give same quantity of TDN and DCP. Generally, the goats fed all rations (FCM + wheat straw) toke their requirements for maintenance plus medium activity and $50 \mathrm{~g}$ weight gain/ day according to NRC (1981).

\section{3- Digestibility of nutrients:}

Using of SBP instead of corn decreased $(\mathrm{P}<0.05)$ the digestibility of $\mathrm{CP}$, EE and NFE (Table 4). These results agreed with those reported by Saleh et al. (2001) who reported that the digestibility of protein significantly declined by increasing SBP level in diet. On the other hand, Talha et al. (2005) reported that no significant effect on digestibility of DM, OM, NFE and CF were obtained by replacing of 40 or $60 \%$ of corn by SBP in CFM of lactating buffaloes. Also, Schmidely et al. (1999) reported that digestibility of nitrogen by goats fed SBP plus slowly degraded nitrogen (coconut meal) and other fed starch plus rapidly degraded nitrogen (horse bean) not differed. The difference between results may be due to: percentage of SBP in rations; source of ingredients; source of protein source and the animal species. SBP increased $(\mathrm{P}<0.05)$ the digestibility of $\mathrm{CF}$. These results are due its lignin content is low (El-Ashry et al., 2000).

Broken horse bean caused significantly $(\mathrm{P}<0.05)$ increase in $\mathrm{DM}, \mathrm{OM}, \mathrm{CF}$ and NFE digestibility. These results may be due to differed amino acid content between HB and cottonseed meal. Also, Schmidely (1999) reported that the nutritive values of extracted materials often less than non extracted.

The interaction between energy and protein sources had significant $(\mathrm{P}<0.05)$ effect on all nutrient digestibility (DM, OM, CP, CF, EE and NFE).

Generally, most results indicate that the best CFM(s) was CFM4 and the lowest one was CFM2. 
Table (2): Feed intake of goats fed tested rations.

\begin{tabular}{lcccc}
\hline Items & Ration & Ration & Ration & Ration \\
& $\mathbf{1}$ & $\mathbf{2}$ & $\mathbf{3}$ & $\mathbf{4}$ \\
\hline Number of animals & 3 & 3 & 3 & 3 \\
Initial live body weight (kg) & 20 & 20 & 20 & 20 \\
Dry matter intake (g): & & & & \\
$\quad$ CFM1 & 600 & ---- & ---- & ----- \\
CFM2 & ----- & 660 & ---- & ---- \\
CFM3 & ----- & ---- & 525 & --- \\
$\quad$ CFM4 & ---- & ---- & ----- & 575 \\
$\quad$ Wheat straw & 65 & 60 & 110 & 75 \\
Total dry matter intake (g) & 3.48 & 3.60 & 3.18 & 3.25 \\
Dry matter intake as \% of live body weight & 441 & 451 & 424 & 434 \\
Calculated TDN intake of FCM (g) & 61 & 61 & 65 & 66 \\
Calculated DCP intake of FCM (g) & & &
\end{tabular}

Table (3): Chemical composition of experimental ingredients and calculated chemical composition of concentrate feed mixtures. \& tested rations.

\begin{tabular}{lccccccc}
\hline Items & \multicolumn{7}{c}{ Chemical composition on dry matter basis (\%) } \\
\cline { 2 - 8 } & DM & OM & CP & CF & EE & NFE & Ash \\
\hline Yellow corn & 94.15 & 98.33 & 9.44 & 2.78 & 4.44 & 81.67 & 1.67 \\
SBP & 95.60 & 94.98 & 10.12 & 20.84 & 0.94 & 63.08 & 5.02 \\
Cottonseed unde. & 92.00 & 93.27 & 23.28 & 23.98 & 14.56 & 31.45 & 6.73 \\
Broken horse bean & 93.50 & 94.42 & 37.28 & 13.97 & 5.48 & 37.69 & 5.58 \\
Wheat straw & 94.00 & 82.14 & 3.31 & 34.29 & 1.98 & 42.5 & 17.86 \\
Calculated chemical composition ( \% ): & & & & & \\
$\quad$ CFM1 & 92.59 & 95.88 & 13.36 & 8.90 & 7.33 & 66.29 & 3.12 \\
CFM2 & 93.27 & 94.31 & 13.68 & 17.39 & 5.69 & 57.55 & 4.69 \\
CFM3 & 93.02 & 96.21 & 17.42 & 6.00 & 4.70 & 68.10 & 2.79 \\
CFM4 & 93.70 & 94.74 & 17.74 & 14.49 & 3.05 & 59.36 & 4.36 \\
$\quad$ Ration1 & 92.78 & 94.01 & 11.99 & 12.37 & 6.60 & 63.05 & 5.13 \\
Ration2 & 93.37 & 93.30 & 12.82 & 18.80 & 5.38 & 56.30 & 5.79 \\
Ration3 & 93.15 & 93.77 & 14.98 & 10.90 & 4.23 & 63.84 & 5.40 \\
Ration4 & 93.78 & 93.29 & 16.08 & 16.77 & 2.93 & 57.49 & 5.92 \\
\hline
\end{tabular}

\section{4- Nutritive values:}

The nutritive values as TDN and DCP\% (Table 5) did not significantly differ between goats fed different energy sources (SBP or corn). On the other hand, protein sources had significantly $(\mathrm{P}<0.05)$ effect $(\mathrm{HB}$ increased TDN and DCP\% in comparison with CSM). The TDN and DCP\% of ration contained CFM2 were significantly $(\mathrm{P}<0.05)$ lower in comparison with other rations. Generally, the highest $\mathrm{DCP} \%$ in group fed on diet contained CFM4 followed by CFM3, CFM1 and CFM2 respectively. Abd El-Rahman, (2005) reported that no significant effect of protein sources (sunflower seed meal, soybean meal and cotton seed meal) on DCP in sheep, 
but the nitrogen balance differed may be due to difference in amino acid composition of protein sources and its digestibility.

The TDN and DCP intake did not affected by replacing of corn by SBP. Also, TDN intake not affected by protein source. The intake of DCP increased $(\mathrm{P}<0.05)$ by HB in comparison with CSM (Table 5).

The interaction between energy and protein sources was significant. The TDN intake not differ significantly between goats fed CFM1, CFM3 and CFM4. The TDN of CFM2 was the lowest one $(\mathrm{P}<0.05)$. The DCP intakes of goats fed CFM4> CFM3> CFM1> CFM1.

\section{5- Rumen parameters:}

The $\mathrm{pH}$ value not affected $(\mathrm{P}<0.05)$ by energy and protein sources. The interaction was significant which the lowest $\mathrm{pH}$ and highest TVFA's were in goats fed CFM1 in comparison with fed other rations. These results may be due to higher microbial activity by rumen microorganisms as indicated by total VFA's production which took place on the soluble carbohydrate very soon producing more propionate decreasing $\mathrm{pH}$ values. While fermentation of the structural carbohydrates need more time producing more acetate delaying the decreased $\mathrm{pH}$ value (Andrighetto et al., 1993 and Nagah, 2002). Similer results were obtained by Schmidely et al. (1999) in lactating goats. Who found that the $\mathrm{pH}$ was low in goat fed diet contain starch plus rapidly degraded protein ( $20 \%$ wheat, $17 \%$ barley, $10 \%$ oats, $25 \%$ horse bean, $20 \%$ pea, 5\% molasses and 3\% minerals) in comparison with fed fiber plus slowly degraded protein (5\% corn gluten feed, $35 \%$ soybean hulls, $20 \%$ coconut meal, $5 \%$ molasses and $3 \%$ minerals).

Ammonia nitrogen concentration did not significantly $(\mathrm{P}<0.05)$ affected by energy sources. On the other hand, CSM increased $(\mathrm{P}<0.05)$ ammonia concentration in comparison with HB. These results agreed with in sacco degradation that obtained by Schmidely et al. (1999). Increasing of ammonia in rumen liquor suggest inefficient use of ruminal NH3 for ruminal proteosynthesis, even when rapidly degraded starch was available for ruminal microorganisms (Sinclair et al., 1995). Also, may be due to the maximum proteolytic and deaminase activities (Rai et al., 1972). On the other hand, the ammonia decreased $(\mathrm{P}<0.05)$ in rumen liquor of goats fed horse bean. Lowering of ammonia may be due to absorption and / or utilization of NH3-N in the synthesis activity of rumen (McDonald, 1952).

Goats fed the SBP as energy source compared with goats fed corn had insignificant higher TVFA's concentration. These results agreed with those reported by Schmidely et al. (1999) on lactating goats. The HB decreased $(\mathrm{P}<0.05)$ TVFA's in rumen liquor of goats in comparison with those fed CSM. Decreasing the VFA's by horse bean may be due to absorption and utilization of its in the synthesis activity of rumen like ammonia. The highest TVFA's were for goats fed corn + cotton seed; SBP + cotton seed; SBP + horse bean then corn + horse bean. The increase of VFA might be due to increasing the activity of microflora on the fermentable carbohydrates (Akin and Borneman, 1989 and Wali, 1994). 


\section{6- Daily body weight gain:}

Replacing $66 \%$ of corn by SBP had no effect on daily body gain. These results may be attributed to that TDN and DCP intake did not affected according to these energy sources (Table 5). On the other hand, the HB increased $(\mathrm{P}<0.05)$ daily weight gain which was $57.79 \mathrm{~g}$ in comparison with 51.19 for goats fed CSM. These results are correlated to increasing of DCP intake by HB. The interaction between treatments was significant $(\mathrm{P}<0.05)$. The daily gain of goats fed CFM1, CFM3 and CFM4 not significantly differed. But daily gain of these treatments was higher $(\mathrm{P}<0.05)$ with goats fed CFM2.

Conclusively, replacing $67 \%$ of corn by SBP $(\mathrm{CFM} 2)$ decreased $(\mathrm{P}<0.05)$ the digestibilities of $\mathrm{CP}, \mathrm{EE}, \mathrm{NFE}$ and daily body weight gain when cottonseed was used as a source of protein. Broken horse bean $(\mathrm{HB})$ increased $(\mathrm{P}<0.05)$ the digestibility of $\mathrm{DM}, \mathrm{OM}, \mathrm{CP}, \mathrm{CF}, \mathrm{NFE}$ and daily body gain with all sources of protein. Most results indicated that the best CFM was CFM4 (SBP plus HB) and the lowest one CFM2 (SBP and CSM).

\section{REFERENCES}

Abdel-Rahman, K.M.; Braghit, G.M.; Omar, S.S. and El-Shakankery, A.A. (2005). Utilization of sunflower plant and its products for ruminants. 1- sunflower seed meal compared with soybean meal and cotton seed meal as protein sources for growing lamps. Egyptian J. Nutrition and Feeds, 8 (1): Special Issue: 307-323.

Agriculture Economics (2000). Institute of Agriculture Economics. Ministry of Agriculture, Egypt.

Akin, D.E. and Borneman, W.S. (1989). The role of rumen fungi in fiber degradation. $J$. Animal Sci., 67 (suppl. 1): 474.

Andrighetto, I.; Bailoni, L.; Cozzi, G. and Berzaghi, P. (1993). Effect of yeast culture addition on digestion in sheep fed a high concentrate diet. Small Ruminant Research, 12: 27-34.

A.O.A.C. (1990). Official Methods of Analysis. The $15^{\text {th }}$ Edition. Association of Official Analytical Chemists, Washington, D.C.

Casper, D.P.; Schingoethe, D.J. and Eisenbeisz, W.A. (1990). Response of early lactation dairy cows fed diets varying in source of nonstructural carbohydrate and crude protein. J. Dairy Sci., 73: 1039-1050.

Con-Way, E.F. (1962). Modification analysis and volumetric error. Rev. Ed. Lookwood. London.

Crawshaw, R. (1990). The real value of sugar beet pulp. British Sugar Beet Review, 58: 42.

Duncan, D.B. (1955). Multiple range and multiple F. test. Biometrics., 11 : 1-42.

El-Ashry, M.A.; Zeba, A.; Motagally, and Maareck, Y.A. (2000). Effect of dried sugar beet pulp in dairy buffalo rations on colostrums, milk yield and composition. Egyptian Journal of Nutrition and Feeds, 3 (1): 15-22.

Eweedah, N.M.; Mahmoud, S.A.; El-Santiel, G. and Ali, M.F. (1999). utilization of sugar beet by-products in feeding ruminants. 1- digestibility, rumen fermentation and nutritive value. Egyptian J. Nutrition and Feeds, 2 (Special Issue): 121-129. 
Garcia, G.; Galvez, J.F.; De Blas, C. (1992). Substitution of barley grain by sugar beet pulp in diets for finishing rabbits. 1- Effect of energy and nitrogen balance. $J$. Appl. Rabbit Res., 15: 1008-1016.

Graham, H.; Hesselman, K. and Aman, P. (1986). The influence of wheat bran and sugar-beet pulp on the digestibility of dietary components in a cereal-based pig diet. J. Nutr., 116 (2): 242-251.

McDonald, I.W. (1952). The role of ammonia in ruminal digestion of protein. Biochem. J., 5: 86-91.

Nagah, H.M. (2002). Use of growth promoters (non hormonal) in rations of growing lamps. M. Sc. Thesis, Fac. of Agric., Ain Shams Univ.

NRC (1981). National Research Council No. 15. Nutrient Requirements of Goats. National Academic Press, Washington, D.C.

Rai, G.S.; Paney, A.B. and Rawat, J.S. (1972). Biochemical and microbial changes in goat rumen under maintenance feeding stander. Indian Vet. J., 49: 1069-1100.

Saleh, M.S.; Eweedah, N.M.; Ali, M.F. and Mohsen, M.K. (2001). Comparison between dried sugar beet pulp and yellow corn as a sourve of energy with berseem in ration of growing lamps. Proceedings of the Scientific Conference on Animal Nutrition. Egyptian J. of Nutrition and Feeds, 4: 231-240.

Schmidely, P.; Lloret-Pujol, M.; Pas, P.; Rouzeau, A. and Sauvant, D. (1999). Influence of feed intake and source of dietary carbohydrate on milk yield and composition, nitrogen balance and plasma constituents of lactating goats. J. Dairy Sci., 82: 747-755.

Sinclair, L.A.; Garnsworthy, P.C.; Newbold, J.R. and Buttery, P.J. (1995). Effect of synchronizing the rate of dietary energy and nitrogen relase in diets with a similar carbohydrate composition on rumen fermentation and microbial protein synthesis in sheep. J. Agric. Sci. (Camb.) ,124: 463-472.

Snedecor, G.W. and Ccochran, W.G. (1982). Statistical Methods. $7^{\text {th }}$ Edition. Iowa State University Press, Ames, U.S.A.

Talha, M.H.; Mourad, R.I.; Zaza, G.H. and Ragheb, E.E. (2002). Effect of partiall substitution of corn grains by dried sugar beet pulp in growing lamb rations on their productive performance. Journal of Agriculture Science, Mansoura University, 27 (8): 5193-5199.

Talha, M.H.; Etman, K.E.I. and Zaki, A.A. (2005). Effect of partial replacement of corn grains by dried sugar beet pulp in lactating buffalo's rations on its productive performance. Egyptian J. Nutrition and Feeds, 8 (1) Special Issue: 1-10.

Van Keulen, J. and Young, B.A. (1977). Evaluation of acid-insoluble ash as a natural marker in ruminants digestibility studies. J. Animal Sci., 44: 282-287.

Wali, T.K. (1994). Role of yeast culture ecosystem and animal performance. Inter. J. Animal Sci., 9: 117.

Warner, A.C.I. (1964): Production of volatile fatty acids in the rumen, methods of measurements. Nutrition Abstract $2^{\text {nd }}$ Review, 34: 339.

Zaza, G.H.M. (2005). Effect of incorporation of biologically treated sugar beet pulp as a non-conventional feedstuff in the diets of growing rabbits. The $4^{\text {th }}$ International Conference on Rabbit Production in Hot Climate, Sharm El-Sheikh, Egypt, 267274. 


\title{
تأثثير مصادر الطاقة وبروتين العليقه على الهضم، قياسات الكرش و الزيادة الوزنية فى ذكور الماعز
}

\author{
صبري عبد الحافظ محمد شحاته* و محمود فتحي احمد الجمل*** . .

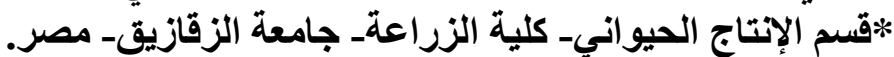

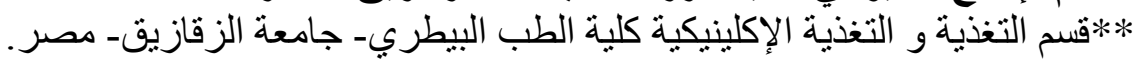

تأثثير مصدرين للطاقة ( الذرة و تفل بنجر السكر) و مصدرين للبروتين( كسب القطن و كسر الفول)

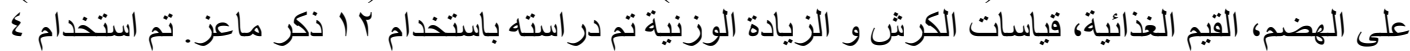

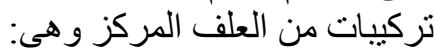

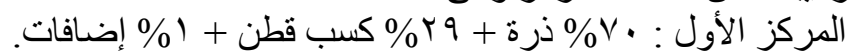
المركز الثاني: rr\%

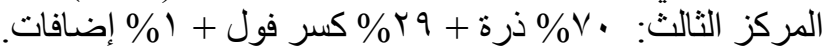
المركز الر ابع: rr\%

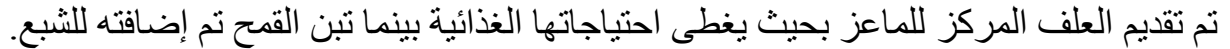

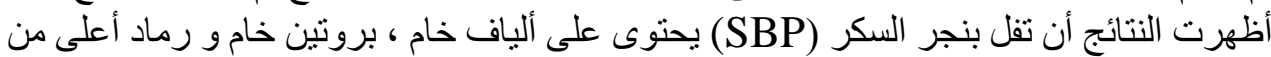

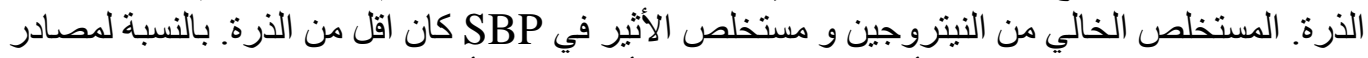

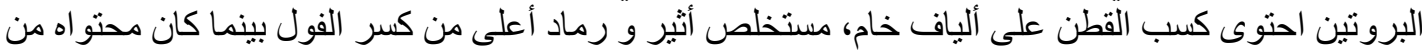

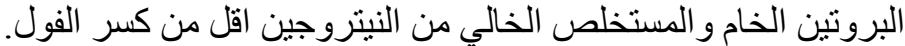
انخفض هضم البروتين الخام ، مستخلص الأثير و المستخلص الخالي من النيتروجين النين معنويا باستخدام

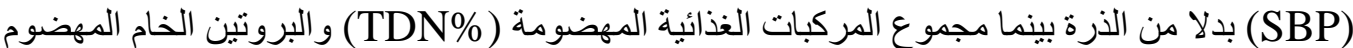

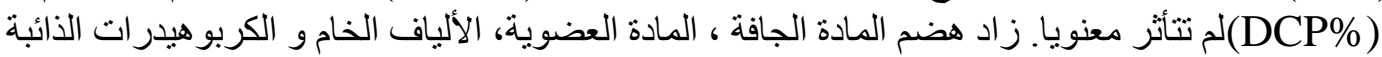
المهضومة، TDN\% و TCP\% بكسر الفول بالمقارنة بكسب القطن. التداخل بين مصادر الطاقة و البرونة البروتين كان له اثر معنوي على معاملات هضم كل المركبات الغذائية و القيم الغذائية.

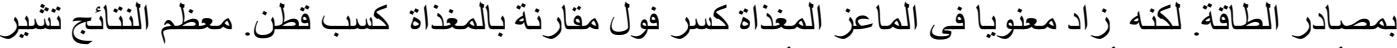
إلى أن المركز الرابع أفضلهم يليه الثالث يليه الأول ثم الثياء الثناني.

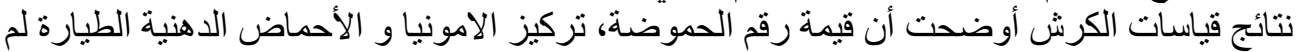

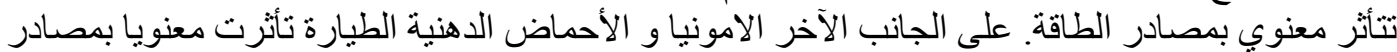

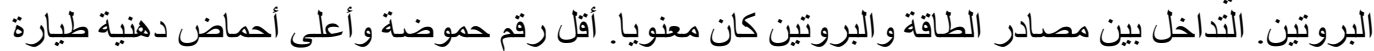

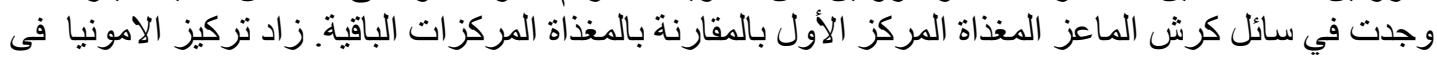
وجود كسب القطن بالمقارنة بكسر الفول.

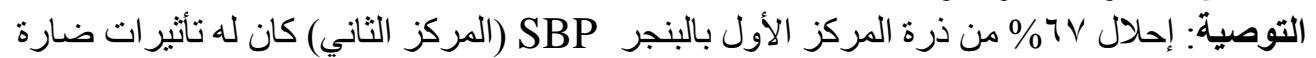

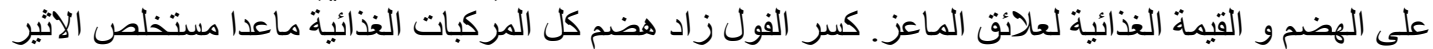

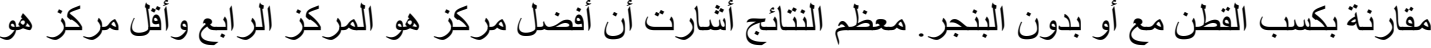

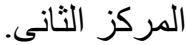

